\title{
Research and Practice on the Teaching Mode of "Innovation and Entrepreneurship" in Vocational Colleges Based on the Integration of Specialty and Innovation -- A Case Study of Urban Planning and Landscape Architecture Group
}

\author{
Fei Nie, Ying Li*
}

\author{
Shandong Urban Construction Vocational College, 4657 tourism road, Jinan, China \\ *Corresponding author. Email: 781460917@qq.com
}

\begin{abstract}
Under the background of education reform, vocational colleges in China have also realized the reform of teaching methods, which has provided a large number of high-quality technical talents for national construction. Nowadays, the teaching mode of "innovation and entrepreneurship" has gradually become one of the main directions of teaching reform in vocational colleges. This paper mainly introduces the construction background of urban planning and landscape architecture group in vocational colleges, analyzes the problems existing in the teaching system of vocational colleges, and puts forward the implementation strategy of "innovation and entrepreneurship" teaching mode of urban planning and landscape architecture group in vocational colleges based on the integration of specialty and innovation, aims to provide reference for the development of "innovation and entrepreneurship" education in vocational colleges.
\end{abstract}

Keywords: Vocational colleges, urban planning and landscape architecture group, integration of specialty

and innovation, teaching mode of "Innovation and Entrepreneurship"

\section{INTRODUCTION}

Since 2015, the state has issued a number of policy documents on promoting innovation and entrepreneurship, and college students' innovation and entrepreneurship has become a focus of common concern.

Nowadays, the training of talents of "innovation and entrepreneurship" has become the key point of deepening the comprehensive reform of education in colleges and universities. Vocational colleges generally attach great importance to the concept of "entrepreneurship and innovation" teaching, gradually apply it to the daily teaching process, combine professional construction, innovate the teaching model, and further improve students' of "innovation and entrepreneurship" ability. However, there are still many problems in the teaching methods of vocational colleges, which need to be further transformed by combining specialty and innovation, so as to avoid the non-specific of "entrepreneurship and innovation" teaching mode in vocational colleges, strengthen the pertinence of specialty education and "entrepreneurship and innovation" education in vocational colleges, improve the comprehensive ability of students.

\section{THE CONSTRUCTION BACKGROUND OF URBAN PLANNING AND LANDSCAPE ARCHITECTURE GROUP}

In China, the purpose of vocational education is to provide high-quality talents with technical skills for the society, so as to adapt to the pace of social production and construction, and take the initiative to adapt to the development needs of regional industrial economy according to the changes of market supply and demand.

The graduates of vocational colleges are one of the important forces in building a modern country. Therefore, according to the development trend of specialty and industry, it is the trend of vocational education to build a model professional organization with industry characteristics.

With the continuous development of China's economy, the pace of urbanization construction is accelerating, which puts forward higher requirements for environmental greening construction. Landscape planning and urban construction have become important contents in economic construction [1]. Therefore, a large number of professional and innovative talents are needed for landscape planning, landscape management and maintenance. In consequence, 
the urban planning and landscape architecture group in vocational colleges came into being, providing more possibilities for eco-development, and contributing to sustainable development.

\section{GENERAL PROBLEMS IN THE TEACHING SYSTEM OF VOCATIONAL COLLEGES}

First, the innovation education of vocational colleges lacks the consciousness of innovation. The teaching and training objectives of vocational colleges lack innovation consciousness, and only clearly define the specific objectives related to the major, and the cultivation of the innovation consciousness and the ability of innovation in the major is relatively rare.

Secondly, the innovation education in vocational colleges emphasizes practical skills and lacks the guidance of innovation skills. Most vocational colleges adopt the school-enterprise combined training mode, and the content of practical teaching mainly includes on-campus training, off-campus training, course design, graduation design, professional-related practical training, social practice and public benefit activities. These methods can greatly improve students' practical skills. However, only the improvement of practical skills is emphasized in the whole teaching process, which lacks the inspiration and training of innovation awareness. The cultivated students can only maintain the basic working status in the grass-roots management or the production line, lacking the awareness of innovation and entrepreneurship [2].

Finally, the innovation content is single, the innovation education management system is not perfect. In terms of the balance between theoretical knowledge, practical skills and comprehensive quality, vocational colleges can attach great importance to the cultivation of students' comprehensive quality and actively strive to cultivate talents with high professional ethics and innovative spirit. However, in the cultivation process, innovation teaching content is relatively single, which leading to innovation education management system cannot be fully improve, training process only emphasize professional knowledge into effect, unable to guide students in entrepreneurship, so it is difficult for students to combine their own conditions to carry out pertinence innovation activities and entrepreneurship activities after work

\section{THE IMPLEMENTATION STRATEGY OF THE TEACHING MODE OF "INNOVATION AND ENTREPRENEURSHIP" FOR THE URBAN PLANNING AND LANDSCAPE ARCHITECTURE GROUP IN VOCATIONAL PLANNING BASED ON THE INTEGRATION OF SPECIALTY AND INNOVATION}

\subsection{Change and Increase the Teaching Concept of Innovation and Entrepreneurship}

Education is related to the improvement of people's ideological level. Therefore, it is necessary to keep pace with the times, actively change the teaching concept, and create a set of "innovation and entrepreneurship" teaching model that conforms to the educational concept of specialty and creativity integration. Continue to highlight the essence of practical teaching, combine professional characteristics, make reasonable predictions on social and market demand, determine basic requirements for professional training, closely link talent training with employment and economic development, and adapt to the society's demand for high-energy talents. On this basis, the new teaching content of innovation and entrepreneurship should be added, the inspiration and training of innovation consciousness should be carried out, and the teaching mode of "innovation and entrepreneurship" in vocational colleges should be constructed with the idea of specialized and innovation integration education as the core, so as to better adapt to the development requirements of the new era.

\subsection{Innovate the Content of Practical Training to Improve Students' Professional Practical Ability}

Based on the original training base, the content of practical training should be innovated to improve students' innovative skills based on professional practical ability, and an innovation and entrepreneurship internship system based on practical training should be established.

Internship in the process of training, the school in accordance with the original content and principles to guide students, at the same time actively use specialized conditions provided by the training base, reserved professional research problem, to provide students space to develop, combining with the professional knowledge to get inspired, promote innovative thinking ability, make students better to apply creative thinking method in the actual work and studies.

The innovation of practical training content and the establishment of practical training innovation system can further improve students' professional practical ability and 
lay an ideological foundation for students to achieve better development in the future.

\subsection{Establish a Support System to Provide Support for Innovation and Entrepreneurship Education}

After the establishment of the teaching system of innovation and entrepreneurship, in order to avoid students from going astray in their future study and work, it is necessary to establish a corresponding guarantee system to provide better support for innovation and entrepreneurship education.

First of all, set up a professional faculty, the professional group of teachers who specialize in innovation and specialty can be composed of high-quality professional teachers of the school and externally hired teachers of innovation and entrepreneurship. On the one hand, the knowledge on innovation and entrepreneurship is perfectly integrated with professional classroom teaching; on the other hand, according to the differences between teaching objectives and students, more professional and careful guidance can be provided for students' future career practice or practical entrepreneurship. In addition, schools can encourage students to independently set up student associations dedicated to innovation and practice, so as to enhance students' awareness of independent innovation, and encourage students to actively participate in various innovation or entrepreneurship projects, so as to exercise their thinking in practice, and strive to get the transformation of thinking and improve their awareness of innovation[3].Finally, in order to ensure the learning effect of students, it is necessary to gradually establish the evaluation model of innovation and entrepreneurship education. For example, the evaluation standard of innovation rate should be added into the content of graduation design. In daily teaching, experimental design or investigation tracking can be used for regular testing.

\section{CONCLUSION}

To sum up, there are still some problems in the teaching system of vocational colleges, such as lack of innovation consciousness, lack of innovation education, emphasis on practical skills, lack of innovation skill guidance, single innovation content and incomplete innovation education management system. Change teaching concept and add new teaching contents of innovation and entrepreneurship; Innovate the content of practical training to improve students' professional practical ability; Establishing a guarantee system to provide guarantee for innovation and entrepreneurship education; The establishment of evaluation mechanism and the improvement of learning effect are the key measures to improve the teaching effect of "innovation and entrepreneurship" in urban planning and landscape architecture group of vocational colleges.

\section{REFERENCES}

[1] Sun xiangyang, Shi lijuan, He binggao. Research on the optimization of practical teaching model under the platform of "innovation and entrepreneurship" cooperation in colleges and universities [J]. Foreign trade and economic cooperation, 2019(08):142-143+156.

[2] Li jiaqi, Liu Yang, Li guihuan, Zhao yubo. Research on the development of innovation and entrepreneurship teaching in vocational colleges [J]. Think tank times, 2019(34):166-167.

[3] Chen weixia. Research on teaching mode of career planning in vocational colleges under the background of integration of specialty and creativity $[\mathrm{J}]$. Journal of Lanzhou institute of education,2019,35(05):146-149. 